\title{
Modification of a strain of Aujeszky's disease virus in cell culture
}

\author{
B. TOMA ( $\left.{ }^{1}\right)$, A. BRUN ( $\left.{ }^{2}\right)$, P. VANNIER ( $\left.{ }^{3}\right)$ et G. CHAPPUIS ( $\left.{ }^{2}\right)$ \\ (1) Ecole Nationale vétérinaive, $9470 \mathrm{~T}$ Maisons-Alfort (France) \\ (2) I.F.F.A., Mérieux, 690oo Lyon (France) \\ ( $\left.{ }^{3}\right)$ Station de Pathologie porcine, 22440 Ploufragan (France)
}

A virulent virus strain isolated in Brittany during an outbreak of the Aujeszky's diseasewas subjected to serial passages on cell culture, by the technique of limit dilutions, at a progressively decreasing temperature, and cloned three times.

At passage 220 , the residual virulence and the immunogenicity of this strain (Alfort 26) were estimated.

The preliminary results show that the strain is harmless for the 2 day-old piglet receiving it by the nasal, intramuscular or intracerebral route. Furthermore, it proves to be immunogenic for the weaned pig.

These primary findings have to be completed by many further investigations.

\section{Immune response of piglets following vaccination with a mixture of two attenuated strains of Hog cholera and Aujeszky' disease viruses obtained in tissue culture at low temperature}

\author{
J. M. AYNAUD (1) et B. TOMA. (2) \\ (1) Laboratoive de Pathologie porcine \\ I.N.R.A., 78850 Thiverval-Grignon (France) \\ (') Ecole Vétérinaive d'Alfort, 9470I Maisons-Alfort (France)
}

A mixed live virus was composed of the "Thiverval" strain of Hog Cholera virus and of the " Alfort-26" strain of Aujeszky's disease virus. These two attenuated strains were obtained in tissue culture at low temperature by means of serial passages at limit dilution. Injected by intramuscular route, the mixed vaccine induced an immune response studied by means of the serum neutralizing antibodies kinetics and by means of the resistance against virulent challenge. Concerning humoral immunity, there was no significant difference in the production of serum neutralizing antibodies specific of both viruses between piglets vaccinated with the mixed vaccine and those inoculated with the "Thiverval" strain of Hog Cholera virus alone or with the "Alfort26 " strain of Aujeszky's disease virus alone. In other words antibodies specific of Hog Cholera and Aujesky's disease viruses were produced in piglets vaccinated with a mixture of the Thiverval and Alfort-26 strains. The mixed vaccine protected piglets against Hog Cholera virulent challenge, but at the present time these preliminary results could not conclude for its activity against Aujeszky's virulent challenge. 